\title{
Lukács diante do Direito e da autonomização da esfera jurídica no capitalismo*
}

\author{
Vitor Bartoletti Sartori*
}

Resumo: Abordaremos a crítica lukácsiana ao Direito. Mostraremos como, segundo o autor, a autonomização da esfera é importante para que ela cumpra sua função na sociedade capitalista. Assim, para que o Direito se coloque de acordo com sua especificidade, ele exerce uma função progressista na emergência do capitalismo e, depois, no momento de decadência ideológica da burguesia, o papel do Direito e dos juristas vem com doses consideráveis de manipulação.

Palavras-chave: Lukács; Direito; ontologia; autonomização do Direito; crítica ao Direito.

\begin{abstract}
We will address the Lukacisian critique of law. We will show how, according to the author, the autonomy of the sphere is important for it to fulfill its function in capitalist society. Thus, for the Law to conform to its specificity, it plays a progressive role in the emergence of capitalism and, later, in the moment of ideological decay of the bourgeoisie, the role of Law and of the jurists comes with considerable doses of manipulation.
\end{abstract}

Keywords: Lukács; Law; Ontology; Autonomization of Law; Critic of Law.

\section{Introdução}

Aqui, ao se ter em mente a especificidade dos distintos complexos sociais, procuraremos mostrar a atualidade e o cuidado da crítica lukácsiana ao Direito. Para tanto, teremos em conta a obra madura do autor, conformada, sobretudo, em seu Para uma ontologia do ser social e em sua Estética. Mesmo que - sobre este tema seja possível partir de importantes textos como Tática e ética ou História e consciência de classe (Cf. ALMEIDA, 2006; SARTORI, 2020), tendemos a concordar com Nicolas Tertulian, que diz sobre as duas obras de maturidade que mencionamos: "as duas últimas grandes obras de György Lukács, representam o ponto culminante de sua atividade teórica, sua maior contribuição à filosofia contemporânea" (TERTULIAN, 2007a, p. 221). ${ }^{1}$ Neste sentido, em nossas explanações sobre o complexo jurídico, pretendemos extrair da ontologia lukácsiana apontamentos, que acreditamos serem essenciais, sobre o tema. Mesmo que aqui não seja possível traçar, com o cuidado devido, os delineamentos mais gerais da temática (Cf.

\footnotetext{
* O texto é uma versão atualizada e modificada de texto no prelo, a ser publicado em coletânea organizada por Lívia Cotrim, Claudinei Cássio e Vitor Sartori.

${ }^{* *}$ Professor da UFMG, doutor pela USP e mestre pela PUC SP; e-mail: vitorbsartori@gmail.com.

1 Para alguns apontamentos nossos sobre a atualidade da filosofia lukácsiana, Cf. Sartori (2010a; 2010b; 2012; 2013; 2014; 2015a; 2015b).
} 
SARTORI, 2010) - nem se contrapor com a ênfase necessária às leituras redutoras ou ecléticas acerca da posição do Direito na obra lukácsiana (Cf. SARTORI, 2015a), ou a crítica do autor à moral (Cf. SARTORI, 2015b) -, abordar a relação entre o Direito e a autonomização dos complexos sociais pode ser importante, tanto para a compreensão desta esfera do ser social, quanto para sua crítica. Neste escrito, pois, apreciaremos a questão da especificidade da esfera jurídica tendo em conta a questão da autonomização das esferas do ser social frente ao momento econômico para que, com isto, seja possível uma apreensão cuidadosa da posição lukácsiana sobre a potencialidade do Direito enquanto campo de lutas sociais. Neste percurso, procuraremos mostrar que, em Lukács, não se tem a busca por um Direito crítico, alternativo, insurgente etc.; antes, há uma crítica ontológica ao Direito. (Cf. SARTORI, 2010, 2015b).

\section{Sobre o Direito na ontologia lukácsiana}

Uma primeira questão a ser levantada, ao se tratar do tema, diz respeito à posição de Lukács quanto ao modo pelo qual se colocam dois equívocos simétricos na apreensão do ser-propriamente-assim da sociedade: de um lado, ter-se-ia certa forma de reducionismo econômico encontrado no marxismo vulgar (e no stalinismo); doutro, haveria a fetichização (mais ou menos mediada) dos complexos do ser social, presente de modo pungente na ciência burguesa. (Cf. LUKÁCS, 1959, 2010, 2013). Como aponta o autor, após realizar sua análise acerca da especificidade do Direito: ${ }^{2}$

\footnotetext{
É possível tirar uma importante conclusão para o funcionamento e a reprodução dos complexos sociais parciais, a saber, a necessidade ontológica de uma autonomia que não pode ser prevista nem adequadamente apreendida no plano lógico, mas que é racional no plano ontológico-social e uma peculiaridade de desenvolvimento de tais complexos parciais. Por essa razão, estes conseguem cumprir suas funções dentro do processo total tanto melhor quanto mais enérgica e autonomamente elaborarem a sua particularidade específica. Isso fica diretamente evidente para a esfera do Direito. (LUKÁCS, 2013, p. 248).
}

Lukács trata do Direito ao passo que diz: "a intenção era apenas dar um vislumbre dos contornos mais gerais desse complexo, visando apreender os

\footnotetext{
2 Importante destacar que os propósitos da análise lukácsiana do Direito são, até certo ponto, bastante modestos. Diz o autor: "nem aqui nem em outro lugar, essas análises se propõem a fazer uma tentativa de esboçar uma ontologia social sistemática da esfera do Direito" (LUKÁCS, 2013, p. 248). Deste modo, a questão do Direito ainda pode ser bastante desenvolvida a partir de Lukács. 0 autor mesmo fala que na Ontologia só fez "parcas e fragmentárias alusões" (LUKÁCS, 2013, p. 248) ao tema. Para um delineamento geral da questão Cf. Sartori (2010). Para uma análise mais cuidadosa da relação entre Direito e moral, Cf. Sartori (2015b); para a relação entre Lukács e a teoria do Direito contemporânea, Cf. Sartori (2015b).
} 
princípios do seu funcionamento" (LUKÁCS, 2013, p. 237). E isto certamente não é pouco, já que implica na busca de uma apreensão cuidadosa da especificidade deste complexo do ser social.

No entanto, claro, não se trata de uma análise exaustiva acerca da temática; até mesmo por ela não se pretender como tal. Este complexo social parcial - que trataremos neste texto somente na medida em que buscamos explicitar o modo pelo qual se coloca o complexo jurídico na obra lukácsiana - seria exemplar ao tratar do desenvolvimento, ao mesmo tempo, unitário de multifacetado do ser da efetividade. Aqui, portanto, procuramos expor somente o modo pelo qual o "pouco" que Lukács trata do complexo jurídico pode ser de enorme ajuda na compreensão acerca do modo como a mediação jurídica se põe no desenvolvimento histórico e objetivo da sociedade capitalista.

A questão é bastante importante, já que, de acordo com Lukács, os próprios "funcionamento e reprodução" dos distintos complexos dependem da "autonomia" de cada complexo parcial ao mesmo tempo em que a reprodução social só pode ocorrer tendo em conta o complexo social total. ${ }^{3}$ Ou seja, o modo pelo qual a totalidade social é conformada enquanto tal depende da autonomia dos complexos parciais (como o Direito), ao mesmo tempo em que esta autonomia não pode figurar senão como um fator, um momento do desenvolvimento do todo (Cf. SARTORI, 2010). Para que tragamos à tona diretamente aquilo que abordamos: segundo o marxista húngaro, o Direito tem sua especificidade e sua autonomia, somente ao passo que se coloca como dependente do desenvolvimento do todo social, do complexo social total. ${ }^{4}$ A conformação objetiva do todo social, por sua vez, depois de

\footnotetext{
${ }^{3}$ Lukács define o ser social como "complexo de complexos". Ter-se-ia "o fato ontológico de que todos os atos, relações etc. - por mais simples que possam se apresentar à primeira vista - são sempre correlações entre complexos, pelas quais os elementos desses têm uma operatividade real somente como parte constitutiva do complexo ao qual pertencem. [...]. De maneira que o ser social, até em seu estágio mais primitivo, representa um complexo de complexos, onde há interações permanentes quer entre os complexos parciais quer entre o complexo total e as partes" (LUKÁCS, 1981, p. IV).

4 Tem-se no ser-propriamente-assim do Direito esta relação que apontamos: "por trás da especialização reiteradamente exigida dos representantes da esfera do Direito, oculta-se um problema referente à reprodução do ser social que não deixa de ser importante. Ao expandir-se quantitativa e qualitativamente, a divisão social do trabalho gera tarefas especiais, formas específicas de mediação entre os complexos sociais singulares, que, justamente por causa dessas funções particulares, adquirem estruturas internas bem próprias no processo de reprodução do complexo total. Com isso, as necessidades internas do processo total preservam a sua prioridade ontológica e, por essa razão, determinam o tipo, a essência, a direção, a qualidade etc. nas funções dos complexos mediadores do ser. Contudo, justamente pelo fato de o funcionamento correto, no nível mais elevado do complexo total, atribuir ao complexo parcial mediador funções parciais particulares, surge nesse complexo
} 
determinado grau de desenvolvimento das sociedades marcadas pelo antagonismo entre classes sociais, é impensável sem a autonomia do complexo jurídico. Tem-se reprodução social da sociedade capitalista e Direito ligados intimamente.

Deste modo, primeiramente, para uma compreensão adequada da questão, devemos ressaltar sobre o que diz o autor: tem-se, na reprodução do ser social, uma autonomia dos complexos parciais que não é simplesmente "epistêmica"; antes, há uma "necessidade ontológica de uma autonomia que não pode ser prevista nem adequadamente apreendida no plano lógico"; aquilo que explica a autonomia do Direito não está colocado, por conseguinte, no terreno de uma teoria do conhecimento que separe distintos "objetos" para ciências parcelares específicas, com "lógicas específicas". ${ }^{5}$ Antes, em meio ao devir das contradições sociais, tem-se a "necessidade ontológica de uma autonomia", de tal feita que o modo pelo qual desenvolve-se a autonomia do Direito depende da própria conformação - histórica e objetiva - da realidade efetiva e das distintas funções que este complexo parcelar têm frente a última (Cf. SARTORI, 2016). Lukács, neste sentido, aponta algo que pode parecer paradoxal à primeira vista: no plano do ser, a autonomia dos distintos complexos do ser social decorre da inseparabilidade mesma destes complexos frente ao todo social (Cf. SARTORI, 2010). A autonomia de cada complexo, pois, não pode ser apreendida no plano "lógico" de modo algum; somente pode ser vista no plano ontológico, em que os complexos parciais "conseguem cumprir suas funções dentro do processo total tanto melhor quanto mais enérgica e autonomamente elaborarem a sua particularidade específica". Para o autor da Ontologia, quanto mais autônomos os complexos, quanto mais eles tiverem desenvolvido "sua particularidade específica", e melhor eles conseguirão se colocar efetivamente em meio à reprodução do ser social. Compreender a especificidade da esfera do Direito - e de outras esferas do ser social - não é somente um exercício de erudição, pois: para Lukács, trata-se de algo essencial para a apreensão do ser-propriamente-assim da sociedade.

parcial - chamada à existência pela necessidade objetiva - certa independência, certa peculiaridade autônoma do reagir e do agir, que precisamente nessa particularidade se torna indispensável para a reprodução da totalidade" (LUKÁCS, 2013, p. 248).

${ }^{5}$ Diz Lukács: "é certo que as obras econômicas do Marx maduro estão centradas coerentemente na cientificidade da economia, mas nada têm em comum com a concepção burguesa, segundo a qual a economia é mera ciência particular, na qual os chamados fenômenos econômicos puros são isolados do conjunto das inter-relações do ser social como totalidade e, depois, analisados nesse isolamento artificial, visando - eventualmente - relacionar de maneira abstrata o território assim formado com outros territórios isolados de modo igualmente artificial (o Direito, a sociologia etc.)" (LUKÁCS, 2012, p. 291). 
Neste sentido, compreender a especificidade do Direito, por exemplo, não significa adentrar de modo acrítico nos meandros da "ciência do Direito" ou da "teoria do Direito" (Cf. SARTORI, 2015a); antes, tem-se a busca pela apreensão da autonomia de cada complexo parcelar ao se tratar do modo como real e efetivamente estes complexos, somente ao passo que se desenvolvem na história com características e determinações específicas, têm funções distintas na realidade efetiva. Assim, para Lukács, captar o ser-propriamente-assim da sociedade somente é possível com uma compreensão cuidadosa da relação existente entre os distintos complexos do ser social entre si e com o complexo social total, a própria sociedade de uma época. $\mathrm{O}$ cuidado que o autor húngaro dedicou à questão da especificidade de cada esfera do ser social em sua Ontologia, de um lado, traz um rigor bastante grande somente possível a alguém com a erudição do autor (Cf. TERTULIAN, 2009) e, doutro, traz uma posição decididamente contrária à conformação da sociedade atual, conformação essa somente compreensível a partir de uma análise cuidadosa da efetividade e contrária ao esquematismo stalinista.

\title{
Sobre a autonomia do complexo do Direito e a atividade dos juristas
}

Relacionada intimamente a esta questão mais geral, tem-se a necessidade de tratar do modo pelo qual a atividade social relaciona-se à autonomia dos complexos sociais parciais, tendo-se, inclusive, uma incompreensão que salta aos olhos no chamado "marxismo vulgar". Sobre o assunto, alerta Lukács na Ontologia:

\begin{abstract}
O próprio desenvolvimento social providencia que daí não resulte nenhuma autonomia absoluta, naturalmente não de modo automático, mas na forma de tarefas a serem cumpridas em cada caso, na forma de reações, atividades etc. humanas que surgem a partir delas, não importando se, nessas questões, essa autonomia se torne mais ou menos consciente, não importando o quanto ela seja mediada ou o quanto seja desigual o modo como ela se impõe. Nessa questão, o marxismo vulgar não foi além da declaração de uma dependência niveladora, mecânica, em relação à infraestrutura econômica (o neokantismo e o positivismo do período revisionista representaram um castigo justo da história por essa vulgarização). O período stalinista, por sua vez, exacerbou novamente essa concepção mecanicista e a transpôs para a práxis social pela força; os resultados são conhecidos de todos (LUKÁCS, 2013, p. 249).
\end{abstract}

A ressalva lukácsiana acerca da inexistência de qualquer autonomia absoluta dos complexos sociais é clara e não deve ser esquecida sob o risco de se ter a adoção de uma posição atribuída pelo autor à ciência burguesa (Cf. LUKÁCS, 1959) esta última, em verdade, já marcada por uma conformação decadente e, no limite, apologética (Cf. LUKÁCS, 1968). Para o autor, como já mencionamos, a autonomia mesma das esferas do ser social decorre do contraditório "desenvolvimento social", 
em correlação com distintas "tarefas a serem cumpridas", "atividades", "formas de reações" por parte de cada complexo parcial. Estas "tarefas", por seu turno, partem da especificidade do desenvolvimento de cada complexo social parcial ao mesmo tempo em que não são compreendidas senão como um fator, um momento da reprodução do todo.

Com isto, tem-se que, segundo Lukács, o ser-propriamente-assim da sociedade traz os nexos objetivos mediante os quais a atividade humana (e a teleologia inerente a esta atividade) operam real e efetivamente por meio de complexos sociais parciais (Cf. LUKÁCS, 2013). E, assim, o critério para que se possa "cumprir funções" de modo mais acertado não é, nem pode ser, epistemológico; está ligado à forma específica mediante a qual se tem - em meio à especificidade de determinado complexo parcelar - um reconhecimento de nexos presentes na própria objetividade do real. Neste sentido específico, aponta o autor húngaro que tudo se dá "não importando se, nessas questões, essa autonomia se torne mais ou menos consciente, não importando o quanto ela seja mediada ou o quanto seja desigual o modo como ela se impõe"; a problemática diz respeito ao modo pelo qual, em sua atividade, por meio de complexos parciais, os homens reconhecem, ativamente estes nexos objetivos. Ou seja, mesmo que se tenham distintas "formas ideológicas" (como o Direito) que operam em meio ao real e diante de diferentes conflitos sociais, ${ }^{6}$ para o autor húngaro, o essencial são os nexos presentes objetivamente na realidade efetiva - a especificidade do Direito, assim, só poderia ser compreendida tendo em conta o modo pelo qual este complexo parcial se coloca frente aos nexos mencionados e presentes na conformação histórica objetiva da efetividade. ${ }^{7}$

Este ponto nos parece central (Cf. SARTORI, 2010). E ele remete ao modo real e efetivo mediante o qual os distintos complexos sociais operam, por meio da atividade dos indivíduos e de modo mediado pelas lutas sociais, na sociedade. Neste sentido, é preciso destacar: mesmo que a autonomia dos complexos sociais seja necessária para a conformação do ser-propriamente-assim da efetividade do ser

\footnotetext{
6 Segundo Marx, há uma relação íntima destas "formas" com os conflitos sociais: "formas ideológicas, sob as quais os homens adquirem consciência desses conflitos" (MARX, 2009, p. 46) entre elas, inclusive, as "formas jurídicas, políticas, religiosas, artísticas e filosóficas" (MARX, 2009, p. 46).

7 Como aponta Ester Vaisman acerca da questão da ideologia em Marx e em Lukács: "assim, em termos gnosiológicos, pode-se determinar se um produto espiritual é falso ou verdadeiro, mas não se pode através disso determinar se ele pode ou não assumir função ideológica. Essa identificação só é possível através do critério ontológico-prático, ou seja, através do exame da função que este pensamento desempenha na vida cotidiana efetiva" (VAISMAN, 2010, p. 51).
} 
social de uma época, isto não significa que aqueles que operam por meio dos complexos parciais tenham consciência acerca da função social que vêm a desempenhar em sua atividade. Muitas vezes, inclusive, tem-se o oposto. No que aponta Lukács:

Os legisladores revolucionários da grande virada no fim do século XVIII agiram, pois, contradizendo seus ideais teóricos gerais, mas em consonância com o ser social do capitalismo, de modo ontologicamente coerente, quando em suas constituições subordinaram o representante idealista da generidade, o citoyen, ao bourgeois, que representava o materialismo dessa sociedade (LUKÁCS, 2010, p. 283). ${ }^{8}$

Justamente porque os "legisladores revolucionários da grande virada do fim do século XVIII" trouxeram uma crença inflamada no citoyen é que, por meio do Direito, teriam tido uma função essencial na defesa da sociabilidade que tem por fundamento o bourgeois. Ou seja, eles agiram de tal modo que tudo se deu "contradizendo seus ideais teóricos" ao mesmo tempo em que, justamente por causa disso, os acontecimentos transcorreram "de modo ontologicamente coerente".

A efetividade da situação não pode ser explanada ao se ter em mente uma "dependência niveladora e mecânica em relação à infraestrutura econômica" à moda do marxismo vulgar, dado que o Direito não é, nem pode ser, um simples epifenômeno da "estrutura econômica". Claro, a questão também não pode ser apreendida sem se ter em conta a relação meandrada do complexo jurídico com o complexo econômico; tal equívoco, ocorreu, em geral, no desenvolvimento da "ciência do Direito". ${ }^{9}$ Trazer o complexo econômico à tona simplesmente não bastaria pois se teria um equívoco grave no marxismo vulgar: ao considerar as determinações econômicas, a infraestrutura econômica da sociedade, tem-se que elas foram pensadas de modo mecanicista e, assim, não se teve em conta qualquer autonomia real e efetiva dos complexos sociais parciais. Se, com a posição que prepondera na "ciência jurídica" burguesa (a autonomização absoluta dos complexos parciais) tudo

\footnotetext{
8 Complementa Lukács com algo importante na compreensão de sua posição sobre os rumos do capitalismo de sua época: "essa avaliação da importância do ser também dominou mais tarde todo o desenvolvimento capitalista. Quanto mais energicamente se desenvolvia a produção, tanto mais o citoyen e seu idealismo se tornavam componentes dirigidos pelo domínio material-universal do capital" (LUKÁCS, 2010, p. 283).

9 Vale apontar que aquele autor mais criticado por Lukács neste meandro é Hans Kelsen. Para uma análise da consolidação da "ciência do Direito" (que tem Kelsen por essencial), Cf. Sartori (2015b). Interessante notar também que as origens do Direito enquanto ciência parcelar dotada de cientificidade remeter a Savigny (criticado por Marx já na Gazeta Renana), Bentham (criticado por Marx duramente em $O$ capital e nos Manuscritos etnológicos) e a Austin (também criticado por Marx nos mencionados Manuscritos. Aqui, infelizmente, não poderemos tratar deste assunto o qual, aliás, está ainda a ser estudado com cuidado.
} 
se dá como se os nexos reais e efetivos presentes na realidade social fossem, ao menos, secundários - no limite, tratando-se de formas de apreensão da realidade que flertam com o irracionalismo (Cf. LUKÁCS, 1959), no marxismo vulgar não se tem a solução para esta posição; tem-se, segundo o autor, algo muito problemático: um flerte com uma forma de "hiperacionalismo" (Cf. LUKÁCS, 1986). Ou seja, segundo o marxista húngaro, tem-se equívocos gêmeos: enquanto um lado procurou fetichizar os complexos sociais parciais como autossuficientes frente às determinações objetivas do ser-propriamente-assim da realidade efetiva, doutro lado, a questão é vista de modo muito unilateral e simplificado pelos autoproclamados marxistas, os quais, em verdade, colocaram-se como seguidores de Stálin, e não do que o autor da Ontologia chama de "marxismo concebido acertadamente". ${ }^{10}$

Segundo Lukács, portanto, a outra face da "autonomia absoluta" é justamente a "declaração de uma dependência niveladora, mecânica, em relação à infraestrutura econômica". O renascimento do marxismo seria necessário e essencial neste cenário.

Em verdade, pois, o marxismo vulgar não se saiu muito melhor que a ciência burguesa, incorrendo em um sério erro - para Lukács, imperdoável - e "cujos resultados são conhecidos de todos". As consequências de tal visão mecanicista seriam nada menos que assombrosas: "o período stalinista [...] exacerbou novamente essa concepção mecanicista e a transpôs para a práxis social pela força". ${ }^{11}$ Não só o stalinismo teria deixado de apreender de modo rigoroso a tessitura da realidade efetiva; as análises stalinistas seriam mecânicas e desconsiderariam a especificidade de cada complexo social parcial. Partindo de uma "dependência niveladora", ter-se-ia um manipulatório claro-escuro e, a partir de uma análise mecanicista, ter-se-ia a justificação de determinada práxis social transposta "pela força". ${ }^{12}$ No lugar da compreensão da real tessitura da sociedade e da meandrada relação entre teoria e práxis, o stalinismo trouxe um taticismo inaceitável, em que "na práxis a atuação não é regulada pela mais profunda inteligência das coisas, ao contrário, essa mais profunda inteligência é construída em função da tática

\footnotetext{
${ }^{10}$ Aponta Lukács, de modo enfático, que "o marxismo, concebido acertadamente, [...] não existe mais. Em seu lugar, temos o stalinismo, e continuaremos a tê-lo ainda por algum tempo" (LUKÁCS, 1972, p. 32). Para que não se deixe dúvida acerca de sua crítica, Lukács complementa: "não há mais marxistas. Nós simplesmente não temos uma teoria marxista" (LUKÁCS,1972, p. 32).

${ }_{11}$ Para uma visão cuidadosa acerca da relação de Lukács com o stalinismo, Cf. Tertulian (2007b).

${ }^{12}$ Segundo Lukács, "o stalinismo é mais que uma interpretação errônea ou uma aplicação descuidada do marxismo; é uma negação do marxismo. Com stalinismo não há teóricos, só táticos" (LUKÁCS, 1972, p. 32).
} 
do agir" (LUKÁCS, 1986, p. 63) Assim, tanto a ciência burguesa como o stalinismo não compreendem a simultânea dependência e autonomia dos distintos complexos sociais que conformam a totalidade da sociedade. Ambos deixam de apreender $o$ ser-propriamente-assim da realidade efetiva de tal modo que seria necessário um verdadeiro renascimento do marxismo, que se colocasse - no plano filosófico contra as degenerações do marxismo e contra a ciência e a filosofia burguesas ${ }^{13}$ e, no campo político e da práxis compreendida no seu sentido mais amplo, contra a democracia burguesa e contra as vicissitudes do stalinismo (Cf. LUKÁCS, 2010; 2012; 2013). ${ }^{14}$ Se o erro da ciência burguesa, no que toca ao Direito, é hipostasiar a autonomia do complexo jurídico, seria igualmente equivocado transpor o Direito como expressão simples da luta de classes concebida taticamente (Cf. SARTORI, 2010, 2015a).

\section{A prioridade do econômico e a especificidade do complexo jurídico}

Neste sentido, seria de grande importância compreender o modo pelo qual, em correlação com as determinações objetivas da realidade social, consegue o complexo jurídico "cumprir suas funções dentro do processo total", simultaneamente, a partir de uma dependência diante do complexo econômico, e de sua autonomia frente a ele. Neste sentido, vale trazer um posicionamento de Lukács, retirado de Marx, segundo o qual o modo específico pelo qual o Direito opera se dá mediante o reconhecimento de nexos objetivos presentes na efetividade do próprio ser social. Diz o autor:

O fato de o sistema vigente do Direito positivo e a fatualidade socioeconômica na vida cotidiana subsistirem lado a lado e se encontrarem ao mesmo tempo emaranhados leva necessariamente aos mais diversos tipos de más interpretações da relação entre ambos. Polemizando contra tal teoria errada de Proudhon e em conformidade com a constatação da prioridade ontológica e da legalidade própria dos processos econômicos, Marx propôs a seguinte definição: "O Direito é apenas o reconhecimento oficial do fato" 15 recém constatada do econômico. Essa definição quase aforística é extremamente rica em conteúdo, contendo já os princípios mais gerais daquela discrepância necessária entre Direito e realidade econômicosocial [...]. A determinação "o fato e seu reconhecimento" expressa com

13 Segundo Lukács, isto implica em uma ontologia do ser social: "o objeto [da ontologia] é o realmente existente; a tarefa é a de investigar o ente com a preocupação de compreender o seu ser e encontrar os diversos graus e as diversas conexões em seu interior" (LUKÁCS, 1969, p. 15).

${ }^{14}$ Lukács aponta que "enquanto os resquícios do período stalinista não forem realmente superados na teoria e sobretudo na prática, nem a superioridade do método marxista no plano do pensamento, nem a do modo de vida socialista real no âmbito do ser social conseguirão assumir uma figura autêntica, visível para o mundo todo, que influencie decisivamente as suas perspectivas" (LUKÁCS, 2013, p. 822).

15 "O Direito nada mais é que o reconhecimento oficial do fato" (MARX, 2004, p. 84). 
exatidão a condição de prioridade ontológica do econômico: o Direito constitui uma forma específica do espelhamento, da reprodução consciente daquilo que sucede de fato na vida econômica. A expressão "reconhecimento" apenas diferencia ainda mais a peculiaridade específica dessa reprodução, ao trazer para o primeiro plano seu caráter não puramente teórico, não puramente contemplativo, mas precipuamente prático (LUKÁCS, 2013, p. 237-238).

A concepção lukácsiana acerca do Direito enquanto complexo social parcial procura romper com os dois equívocos que apontamos acima. O "reconhecimento" que trata o autor húngaro coloca-se "ao trazer para o primeiro plano seu caráter não puramente teórico, não puramente contemplativo, mas precipuamente prático". E, assim, tem-se justamente o modo pelo qual a atividade jurídica cumpre funções dentro do processo total relacionado ao fato segundo o qual "o reconhecimento só pode adquirir um sentido real e razoável dentro de um contexto prático" (LUKÁCS, 2013, p. 238); e, neste sentido, fica clara a necessidade de um complexo específico capaz de reconhecer os nexos presentes na "vida econômica" ao mesmo tempo em que, para fazê-lo, precisa de uma heterogeneidade e de uma autonomia efetivas diante da primeira. Neste sentido, se Proudhon traz um elogio ao suposto caráter demiúrgico do complexo jurídico como algo central - e verdadeiro - (Cf. MARX, 2004), equivoca-se substancialmente: ${ }^{16}$ mesmo que sem o Direito determinadas legalidades presentes na "vida econômica" não possam operar na realidade efetiva de modo adequado, segundo Lukács, isto não significa que o complexo jurídico seja capaz de "criar" nexos econômicos (Cf. SARTORI, 2014). Neste sentido, aponta o marxista húngaro "que determinação 'o fato e seu reconhecimento' expressa com exatidão a condição de prioridade ontológica do econômico". E ela, simultaneamente, pressupõe a "discrepância necessária entre Direito e realidade econômico-social".

Ou seja, ela tem como momento necessário a autonomia do complexo jurídico ao mesmo tempo em que tal autonomia só é colocada real e efetivamente ao reconhecer praticamente nexos objetivos presentes na própria realidade efetiva. E, assim, sem nunca deixar de ter um caráter ativo na reprodução do ser social, "o Direito constitui uma forma específica do espelhamento, da reprodução consciente daquilo que sucede de fato na vida econômica". O modo como este espelhamento se dá pode variar substancialmente e, como mencionamos, nem sempre se tem uma

16 Segundo Engels, "toda a doutrina de Proudhon assenta neste salto de salvação que vai da realidade econômica para a frase jurídica. $O$ valente Proudhon, sempre que deixa escapar a conexão econômica - e isto acontece nele com todas as questões sérias - refugia-se no campo do direito e apela para a justiça eterna" (ENGELS, 1982, p. 12). 
apreensão reta do ser-propriamente-assim da sociedade (Cf. SARTORI, 2010). Resta claro, assim, que a "prioridade ontológica do econômico" é essencial ao autor, ao mesmo tempo em que, por si só, não explicita a peculiaridade do Direito. Se os "legisladores revolucionários" mencionados pelo marxista húngaro colocaram-se efetivamente ao lado do desenvolvimento da sociabilidade burguesa, "contradizendo seus ideais teóricos gerais, mas em consonância com o ser social", é preciso que se trate do modo pelo qual se conforma a autonomia do Direito em meio ao desenvolvimento social.

Para tanto, é preciso que se perceba o modo heterogêneo pelo qual o Direito se coloca frente à economia em correlação com a "discrepância necessária entre Direito e realidade econômico-social", ao mesmo tempo em que isto precisa ocorrer ao se ter em mente a conformação da própria "ciência do Direito". Têm-se, ao mesmo tempo, um complexo que precisa "cumprir suas funções dentro do processo total" e um modo específico de conformação da autonomia deste complexo parcial do ser social. Autonomia relativa e dependência diante do econômico são essenciais neste processo.

\section{Gênese e função do Direito no capitalismo}

Ao tratar da relação entre os distintos complexos parciais entre si, bem como da relação entre estes complexos e o complexo social total (a totalidade da sociedade), a abordagem lukácsiana é essencialmente histórica, buscando explicitar a relação existente entre a gênese, a estrutura e a função dos complexos sociais (Cf. TERTULIAN, 2009). Novamente, portanto, a questão principal para Lukács não é a apreensão de uma base epistêmica a partir da qual seja possível apreender a complexidade da tessitura do real; se, em uma ontologia, trata-se de "investigar o ente com a preocupação de compreender o seu ser e encontrar os diversos graus e as diversas conexões em seu interior" (LUKÁCS, 1969, p. 15), isto significa que é central a busca pelo processo real, efetivo e unitário mediante o qual a conformação objetiva do complexo social em questão se deu. Ou seja, trata-se da apreensão da objetividade, da processualidade e da historicidade do ser da própria sociedade. Diz Lukács, neste sentido, que seria preciso tratar da gênese, e mesmo do fenecimento do Direito: "os limites histórico-sociais da gênese e do fenecimento da esfera do Direito estão determinados fundamentalmente como limites temporais" (LUKÁCS, 2013, p. 244). E, assim, é essencial o processo mediante o qual, com o surgimento 
do Estado e da propriedade privada, tem-se, em meio ao desenvolvimento da divisão social do trabalho, também o surgimento do Direito. ${ }^{17}$

A forma de regulamentação jurídica, de acordo com Lukács, tem sua gênese e sua função indissolúveis do processo de desenvolvimento das sociedades classistas e, em especial, da sociedade capitalista (Cf. SARTORI, 2016). Isto se dá porque, mesmo que o autor da Ontologia considere formas pré-capitalistas de Direito (grego, romano, por exemplo), aquilo que dá a especificidade do complexo jurídico em seu sentido mais forte é certo modo de totalização, colocado em uma forma universal de regulamentação social. Esta forma desenvolve-se de modo indissolúvel da centralização do poder estatal, e é, segundo Lukács, convergente com o momento em que a relação-capital começa a perpassar de modo abrangente o complexo social total - trata-se do processo em que a dimensão política e a dimensão jurídica (correlacionadas às contradições ligadas à oposição entre as figuras do bourgeois e do citoyen), "se tornavam componentes dirigidos pelo domínio material-universal do capital" (LUKÁCS, 2010, p. 283). Neste contexto, tem-se, com este domínio, o embate entre a "regulação universal jurídica de todas as atividades" e a outras formas de regulamentação social, de tal modo que, aponta o autor húngaro em Para uma ontologia do ser social:

O fato de que, por exemplo, na Idade Média, o poder estatal fosse descentralizado, de que indivíduos pudessem dispor não só de armas, mas também de séquitos maiores ou menores de homens armados, fazia com que, naqueles tempos, a imposição de um decreto emanado do Direito estatal muitas vezes se tornasse uma questão de combate aberto entre o poder central e a resistência contra ele. A socialização da sociedade impôs nesse ponto formas de transição tão paradoxais, que para certas épocas o conteúdo do Direito passa a ser avaliar em que casos tais resistências são juridicamente válidas. Aqui não é o lugar de esmiuçar as contradições

17 Continua Lukács apontando as relações entre continuidade e descontinuidade acerca do tema: "gênese e fenecimento são, assim, duas variações qualitativamente peculiares, inclusive unitárias de tais processos, que, na superação, contêm elementos de preservação e, na continuidade, momentos de descontinuidade. Assim sendo, já apontamos para o fato de que o estado pré-jurídico da sociedade gera necessidades da própria regulação, nas quais está compreendida em germe a ordem jurídica - todavia qualitativamente diferenciados. Todavia, não se pode jamais esquecer quanto a isso que, por trás dessa continuidade, se oculta uma descontinuidade: o ordenamento jurídico em sentido próprio só surge quando interesses divergentes, que poderiam, em cada caso singular, insistir numa resolução violenta, são reduzidos ao mesmo denominador jurídico, são juridicamente homogeneizados. $\mathrm{O}$ fato de esse complexo tornar-se socialmente importante determina a gênese do Direito na mesma medida em que o fato de ele se tornar socialmente supérfluo em termos reais será o veículo do seu fenecimento. Corresponde ao seu caráter puramente ontológico, que essas considerações não têm, também nessa questão, a intenção de - utopicamente - ir além do caráter ontológico geral, claramente reconhecido por Marx, das constatações desse contexto. Todo perguntar enfático pelo como de sua realização é uma questão de desenvolvimento futuro, que não se pode prever concretamente" (LUKÁCS, 2013, p. 244-245). 
dessas teorias; elas decorrem principalmente da problemática da passagem contraditória do feudalismo para o capitalismo, que necessariamente procurou. Aqui não é o lugar para implementar uma regulação jurídica universal de todas as atividades sociais, como também simultaneamente transformou em questão principal da vida social a superioridade e, desse modo, a autoridade da regulação central perante todas as demais (LUKÁCS, 2013, p. 235).

O modo pelo qual se conforma o Direito, em sua especificidade, e em sua abrangência totalizante, passa pela transição da sociedade feudal para a sociedade capitalista (Cf. SARTORI, 2016). Somente nesta última, com base em relações de produção que abrangem tendencialmente a totalidade das relações sociais de uma época, é que se coloca real e efetivamente a universalidade do complexo jurídico.

O Direito, pois, é, ao mesmo tempo, uma forma de expressão da "socialização da sociedade" e o sintoma de uma forma de sociabilidade em que esta socialização se dá de modo essencialmente antagônico e estranhado (Cf. SARTORI, 2010). Neste contexto, aquilo que diz Lukács acerca da gênese do Direito ("o ordenamento jurídico em sentido próprio só surge quando interesses divergentes, que poderiam, em cada caso singular, insistir numa resolução violenta, são reduzidos ao mesmo denominador jurídico, são juridicamente homogeneizados") ganha um sentido peculiar. Isto ocorre porque a redução "ao mesmo denominador jurídico" perpassa a estrutura de uma sociedade em que a mediação mercantil se impõe "pelo domínio material-universal do capital" e diuturnamente, aparece como evidente no cotidiano e na conformação da tessitura da sociedade (Cf. SARTORI, 2010). E, assim, concomitante à universalização da mediação econômica que passa pela expansão da relação-capital - e pelo consequente desenvolvimento de um mercado tendencialmente mundial - tem-se a "regulação jurídica universal de todas as atividades sociais" como uma necessidade na "passagem contraditória do feudalismo para o capitalismo". A questão acerca do "combate aberto entre o poder central e a resistência contra ele" (o feudalismo) é, assim, a expressão e o reconhecimento da universalização de uma forma de sociabilidade que, política e juridicamente, não reconhece mais os privilégios medievais. Esta forma de sociabilidade traz um "mesmo denominador jurídico", que, com o desenrolar da sociedade capitalista, veio a aparecer em meio à noção jurídica de igualdade, inseparável da expansão da relação-capital e da circulação capitalista de mercadorias. ${ }^{18}$

\footnotetext{
${ }^{18} \mathrm{Em}$ relação à pretensa autonomia do Estado e do Direito, aponta Lukács: "em suma: quanto mais típica deste idealismo estatal, torna-se aparentemente e formalmente autônomo em relação à vida real
} 
Em meio a este processo, o páthos inicial do Direito é bastante nivelador ao trazer a ruptura com uma ordem com o "poder estatal descentralizado" e com relações de produção colocadas de modo igualmente pulverizado; a centralização do poder estatal, que tem por base real a expansão da relação-capital, o "domínio material-universal do capital", traz a igualdade jurídica e, posteriormente, a igualdade política e jurídica frente ao Estado. Segundo Lukács, isto se dá em oposição ao privilégio feudal, e, com isso, trata-se de garantir "a imposição de um decreto emanado do Direito estatal".

O Direito, por conseguinte, coloca-se enquanto um mediador com abrangência totalizante real e efetivamente somente em meio à passagem contraditória do feudalismo para o capitalismo. Neste contexto, em que a sociabilidade burguesa se impõe, o modo pelo qual esta imposição aparece traz a possibilidade de uma forma de "reconhecimento oficial" somente ao passo que se tem a "questão principal da vida social a superioridade e, desse modo, a autoridade da regulação central perante todas as demais" Ou seja, no desenvolvimento social, o reconhecimento jurídico é marcado por lutas sociais (lutas de classe) em que o desenvolvimento do complexo jurídico enquanto uma forma de "regulação jurídica universal de todas as atividades sociais" vai ao encontro do desenvolvimento da sociedade civil-burguesa. $O$ essencial para o que tratamos aqui aparece ao passo que, para o autor húngaro, tanto mais isso se dá, mais os elementos autônomos conformados enquanto complexos parciais "se tornavam componentes dirigidos pelo domínio material-universal do capital".

Ao mesmo tempo em que o páthos original do Direito em meio a este processo pode ter sido também aquele dos "legisladores revolucionários da grande virada do fim do século XVIII", tratou-se, ao final, daquilo que viria a se desenvolver "em consonância com o ser social do capitalismo, de modo ontologicamente coerente, quando em suas constituições subordinaram o representante idealista da generidade, o citoyen, ao bourgeois, que representava o materialismo dessa sociedade".

Neste momento, segundo Lukács, resta clara a natureza, sobretudo prática, do

da sociedade, quanto mais se torna capaz de aparecer como puro órgão da vontade ideal do povo, tanto mais ele se torna adequado a servir como instrumento para implementar os interesses egoístas de grupos capitalistas - e isso precisamente sob a aparência de uma liberdade e igualdade ilimitadas. Talvez aqui o termo 'aparência' não seja inteiramente exato. Com efeito, aqui não se afirma simplesmente uma aparência de liberdade e de igualdade, mas precisamente sua essência econômica, ou seja, o que liberdade e igualdade efetivamente representam na circulação capitalista das mercadorias" (LUKÁCS, 2008, p. 93). 
reconhecimento jurídico, tendo-se "seu caráter não puramente teórico, não puramente contemplativo, mas precipuamente prático" $\mathrm{Na}$ imposição "da regulação central perante todas as demais", o páthos do Direito pode até mesmo ser visto enquanto algo efetivamente revolucionário. Ele é um elemento constitutivo da dissolução da sociabilidade feudal e da implementação da mediação totalizante do capital. Figuras de um ímpeto jusnaturalista e idealista (trata-se, sobretudo, do "representante idealista da generidade, o citoyen") têm um papel importante neste momento em que, de acordo com o autor da Ontologia, na medida mesma em que o Direito não tem como se elevar acima do "nível de generidade que lhe é inerente" (LUKÁCS, 2013, p. 243) - aquele nível do "mesmo denominador jurídico" que reconhece os nexos objetivos presentes no desenvolvimento contraditório da sociabilidade capitalista -, ele traz "a aspiração absurda de ancorar, em termos de conhecimento e em termos morais-legais, no próprio sistema da ordem social vigente, as transformações radicais dessa ordem, que naturalmente abrangem também a de seu sistema jurídico" (LUKÁCS, 2013, p. 235-236).

Ou seja, na gênese mesma da especificidade do Direito capitalista que se coloca como um mediador universal, tem-se o convívio de uma tensão entre o Direito natural sedento de "justiça" e o Direito positivo que vem, também por meio do páthos do jusnaturalismo, a reconhecer "o ser social do capitalismo" e o "domínio material-universal do capital" como sua base real e efetiva.

A tensão mesma entre Direito positivo e justiça aparece, pois, como constitutiva da especificidade do complexo jurídico e Lukács não deixa de perceber-se disso (Cf. SARTORI, 2010). ${ }^{19}$

Somente em meio a esta tensão e, com recurso à "a aspiração absurda de ancorar, em termos de conhecimento e em termos morais-legais, no próprio sistema

\footnotetext{
${ }^{19}$ Como aponta Lukács, "a fim de promover a mediação entre Direito e necessidade de justiça, a reflexão sobre o Direito produz, por seu turno, a concepção peculiar do Direito natural, igualmente um sistema do dever social, cujo pôr, no entanto, objetiva alçar o seu sujeito acima do estado concreto de Direito existente em cada oportunidade. Esse sistema, dependendo das necessidades da época, é concebido como determinado por Deus, pela natureza, pela razão etc. e, por isso, deve estar capacitado para ultrapassar os limites impostos pelo Direito positivo. Como Kelsen reconheceu corretamente, as duas tendências têm trajetos paralelos: intenção, finalidades etc. de uma facilmente continuam nas de outra, pois ambas devem almejar, sem ter consciência crítica de si mesmas, na mesma medida, um estágio da generidade mais elevado do que o realizável no Direito positivo. Só na Ética será possível expor por que nem a complementação pela moral nem todas as iniciativas reformistas no Direito natural e a partir dele foram capazes de elevar o Direito acima do nível de generidade que lhe é inerente" (LUKÁCS, 2013, p. 242-243).
} 
da ordem social vigente, as transformações radicais dessa ordem, que naturalmente abrangem também a de seu sistema jurídico", é que o Direito pôde adquirir sua autonomia e pôde também realizar as "tarefas a serem cumpridas", as "atividades", as "formas de reações" que eram possíveis, e até certo ponto necessárias, em meio ao ser-propriamente-assim do capitalismo em processo de consolidação. A "prioridade ontológica" do econômico, no caso do complexo jurídico, expressa-se justamente ao passo que, neste processo, o Direito pretende ser um demiurgo do real sem nunca poder sê-lo efetivamente (Cf. SARTORI, 2014).

A estrutura mesma deste complexo parcial traz consigo a oposição entre Direito positivo (consolidado no reconhecimento de nexos objetivos presentes em determinado modo de produção), a noção de justiça e o Direito natural, os quais, com base neste mesmo modo de produção, pretendem ultrapassar as vicissitudes do presente de uma forma idealista (o que, para Lukács, é impossível).

Em "termos morais-legais", sem poder questionar sua base real e efetiva, que está "no próprio sistema da ordem social vigente", busca este complexo o Direito natural e o recurso à noção de justiça para supostas "transformações radicais dessa ordem". ${ }^{20}$ A questão se coloca de modo que não se trataria - segundo a concepção jurídica - tanto do "reconhecimento oficial do fato", mas de tentar, em "termos morais-legais", superar aquilo que não tem como se ultrapassar sem negar "o ser social do capitalismo" (Cf. SARTORI, 2015b). Tem-se, assim, "um sistema do dever social, cujo pôr, no entanto, objetiva alçar o seu sujeito acima do estado concreto de Direito existente em cada oportunidade" (LUKÁCS, 2013, p. 243) convivendo lado a lado com "tarefas a serem cumpridas", as "atividades", as "formas de reações" bastante coerentes com a implementação da sociabilidade capitalista. De acordo com Lukács, esta dualidade está presente no ser-propriamente-assim do Direito.

Até certo ponto, pode-se dizer que é justamente esta peculiaridade do Direito

20 Diz Lukács: "nesse ponto, só podemos apontar para o fato de que o sonho de justiça inerente a todas essas exigências, enquanto ele precisar ser e for concebido nos termos do direito, não poderá levar além de uma concepção - em última análise, econômica - de igualdade, da igualdade que é determinada de modo socialmente necessário a partir do tempo de trabalho socialmente necessário e que se concretiza no intercâmbio de mercadorias, tempo de trabalho socialmente necessário que deve permanecer como base real e, por essa razão, insuperável no pensamento, de todas as concepções jurídicas de igualdade e justiça. A justiça que emerge daí consta, por sua vez, no rol dos conceitos mais ambíguos no desenvolvimento humano. Ela assume a tarefa, para ela insolúvel, de harmonizar idealmente ou até institucionalmente a diversidade e peculiaridade individual dos homens com o julgamento dos seus atos com base na igualdade produzida pela dialética do próprio processo da vida social" (LUKÁCS, 2013, p. 243). 
que permite que a autonomia deste complexo parcial traga consigo "ideais teóricos" a serem contraditos pela própria função social da esfera jurídica. Em sua gênese, ao menos no desenvolvimento de sua especificidade no capitalismo (colocada na "regulação jurídica universal de todas as atividades sociais"), o Direito - segundo o autor da Ontologia - aproxima-se da implementação da relação-capital em termos globais, ao passo que também se coloca bastante ligada à esfera política, expressa por meio da noção de citoyen. Esta proximidade entre a esfera política e a jurídica, no contexto da linha ascendente da sociabilidade do capital, trouxe um páthos revolucionário. Este último tem um duplo aspecto: de um lado, procurou opor-se às vicissitudes de sua época por meio da noção de justiça e do Direito natural. Doutro lado, justamente, com essa oposição "idealista" à sua época, ele a consolida em seus termos reais e efetivos. O "sistema de dever social" jusnaturalista, pois, desenvolvese ao opor-se ao seu duplo e ao nunca questionar "o próprio sistema da ordem social vigente".

De acordo com Lukács, este questionamento com base na "justiça" e no Direito natural trata de aspectos fenomênicos da realidade efetiva acreditando serem eles o essencial; tal questionamento procura opor-se "em termos morais-legais" àquilo que só pode ser derrubado com lutas sociais que, explicitamente, procurem a supressão da própria relação-capital. Deste modo, pois, surge uma contraditória autonomia do Direito: na medida mesma em que só pode reconhecer padrões colocados na própria realidade social, acredita criá-los; segundo Lukács, isto decorre da relação existente entre "tarefas a serem cumpridas", as "atividades", as "formas de reações", de um lado, e doutro, o modo pelo qual a consolidação da ordem capitalista necessitava de um posicionamento revolucionário, de um páthos revolucionário e até certo ponto (aquele da igualdade jurídica), nivelador.

\section{Autonomização do Direito e desenvolvimento capitalista}

Vimos, portanto, como que - na obra lukácsiana - a especificidade e a autonomia do complexo jurídico desenvolvem-se histórica e objetivamente. Deste modo, a relação do Direito com a socialização da sociedade e com o processo contraditório de passagem do feudalismo ao capitalismo restou explicitado. No entanto, aquilo que dissemos não trouxe ainda à tona o modo pelo qual, depois de consolidado o modo de produção capitalista, opera real e efetivamente a esfera jurídica em meio ao complexo e antagônico acontecer social. Neste sentido, Lukács 
aponta:

Foi a abrangência total cada vez mais abstrata do Direito moderno, a luta para regular juridicamente o maior número possível de atividades vitais sintoma objetivo da socialização cada vez maior da sociedade -, que levou ao desconhecimento da essência ontológica da esfera do Direito e, por essa via, a tais extrapolações fetichizantes [do Direito enquanto um demiurgo do real, V.B.S.] O século XIX, o surgimento do Estado de Direito que foi se aperfeiçoando gradativamente, fez com que esse fetichismo aos poucos esmaecesse, mas apenas para dar origem a um novo. À medida que o Direito foi se tornando um regulador normal e prosaico da vida cotidiana, foi desaparecendo no plano geral o páthos que adquirira no período do seu surgimento e mais fortes foram se tornando dentro dele os elementos manipuladores do positivismo. Ele se torna uma esfera da vida social em que as consequências dos atos, as chances de êxito, os riscos de sofrer danos são calculados de modo semelhante ao que se faz no próprio mundo econômico (LUKÁCS, 2013, p. 236).

O modo pelo qual o "domínio material-universal do capital" se apresenta em um nível jurídico relaciona-se intimamente com a "regulação jurídica universal de todas as atividades sociais" e com "a abrangência total cada vez mais abstrata do Direito moderno". Deste modo, as lutas de classe que permeiam o ser do complexo jurídico se apresentam como algo até certo ponto nivelador (ligado à noção jurídica de igualdade) e que procura fazer com que os conflitos sociais sejam "reduzidos ao mesmo denominador jurídico, [e, assim] são juridicamente homogeneizados" (LUKÁCS, 2013, p. 244). Neste sentido, o modo pelo qual se dá "a luta para regular juridicamente o maior número possível de atividades vitais" reveste as lutas sociais que ocorrem na passagem do feudalismo ao capitalismo trazendo a "abrangência total cada vez mais abstrata do Direito moderno"; a redução de tudo ao "mesmo denominador jurídico", ao mesmo tempo, é irracional e efetiva: de um lado, é efetiva, dado que, realmente, até mesmo como "sintoma objetivo da socialização cada vez maior da sociedade", o Direito se torna um mediador tendencialmente universal da atividade humana realizada na sociedade capitalista. Doutro lado, porém, tal redução é bastante irracional: no seu próprio processo formativo, o Direito moderno traz um ímpeto supostamente demiúrgico que o cega diante daquilo que the dá base real e efetiva. Assim, a irracionalidade da esfera jurídica se coloca ao passo que, o "aperfeiçoamento" do Direito e do "Estado de Direito" leva a este complexo parcial "ao desconhecimento da essência ontológica da esfera do Direito".

Ao desenvolver seu ser-propriamente-assim, o complexo jurídico aparece em seu duplo aspecto: procura um espelhamento adequado do ser social da sociedade e se vê como incapaz de realizá-lo devido à sua própria especificidade (Cf. SARTORI, 2010). 
O seu páthos inicial procura contrapor, sem que isso fosse possível, tipos diversos de "sistema de dever social" ao ser-propriamente-assim da sociedade. Ao passo que reconhece nexos objetivos presentes na realidade efetiva, o Direito moderno enxerga-se, porém, como demiurgo deles.

E, assim, seu ímpeto inicial e revolucionário, neste momento de conformação do Direito burguês, é inseparável do momento contraditório de passagem do feudalismo ao capitalismo. Neste momento, tem-se, inclusive, "legisladores revolucionários"; com seu ímpeto democrático-revolucionário (Cf. LUKÁCS, 2010), eles agiram "contradizendo seus ideais teóricos gerais, mas em consonância com o ser social do capitalismo". Este é o cenário em que se tinha no complexo jurídico o "páthos que adquirira no período do seu surgimento". Trata-se do simultâneo processo da "abrangência total cada vez mais abstrata do Direito moderno", da "regulação jurídica universal de todas as atividades sociais", mas, principalmente, da consolidação do "domínio material-universal do capital". Portanto, pode-se enxergar que, depois de determinado momento - depois da consolidação deste domínio -, o ímpeto revolucionário do complexo jurídico vai "desaparecendo": na medida em que se tem o "surgimento do Estado de Direito" e de seu "aperfeiçoamento", tem-se um salto correspondente ao momento da decadência ideológica da burguesia (Cf. LUKÁCS, 1968).

Tem-se o termo do período heroico da burguesia, em que, claramente, prepondera um ímpeto jusnaturalista que procura "realizar" a justiça. Do ímpeto revolucionário, necessário para a consolidação da "regulação jurídica universal de todas as atividades sociais" e do "domínio material-universal do capital", passa-se à "prosa" da sociedade capitalista consolidada - Lukács é claro: "depois de 1848 a sociedade capitalista se apresenta já com toda a sua fealdade consumada" (LUKÁCS, 1965, p. 106). O Direito, como "reconhecimento oficial do fato", apenas reconhece esta "fealdade", mesmo que trate de pintá-la com tintas mais "abstratas" e homogeneizadoras.

A "abrangência total cada vez mais abstrata do Direito moderno" consolida este processo. No entanto, com esta forma de consolidação, o salto qualitativo da esfera jurídica se dá de modo que a "realização" do páthos inicial o leva a um patamar em que o "Direito foi se tornando um regulador normal e prosaico da vida cotidiana" juntamente com a preponderância de uma abordagem diretamente 
reificadora e reificante (Cf. SARTORI, 2010): "foi desaparecendo no plano geral o páthos que adquirira no período do seu surgimento e mais fortes foram se tornando dentro dele os elementos manipuladores do positivismo" A preponderância de uma abordagem positivista frente a uma jusnaturalista é parte do próprio processo constitutivo da efetividade do ser social do capitalismo. E, deste modo, não obstante ainda se tenha que "o sistema vigente do Direito positivo e a fatualidade socioeconômica na vida cotidiana subsistirem lado a lado e se encontrarem ao mesmo tempo emaranhados", o modo pelo qual o complexo jurídico traz as "tarefas a serem cumpridas", as "atividades", as "formas de reações" muda a favor de um elemento claramente manipulatório.

Se com o jusnaturalismo e com a noção de justiça, em meio à consolidação da sociedade capitalista, o Direito procurava se apartar da esfera econômica e se colocar como uma espécie de demiurgo do real, depois da consolidação do "domínio material-universal do capital", tem-se a aceitação das vicissitudes da sociedade civilburguesa de tal modo que se opera conscientemente na superfície desta. A passagem do páthos original do Direito moderno à sua expressão no positivismo representa dois ímpetos gêmeos: a busca por um fundamento metafísico e apologético para a ordem social, e o rechaço à compreensão de qualquer forma de fundamentação real e efetiva do ser-propriamente-assim da sociedade. Esta dualidade passa a fazer parte do ser mesmo do complexo jurídico, que se autonomiza diante da realidade social na medida mesma em que é apologético a esta.

No século XIX, época em que escrevem Bentham, Austin e Savigny, pais da "ciência" e da "teoria do Direito", consolida-se o "Estado de Direito" e, segundo Lukács, justamente neste processo, surge uma forma de fetichismo que, no desenvolvimento social, vai trazendo o ímpeto manipulatório para o seio da autonomia do complexo jurídico: com isto, "mais fortes foram se tornando dentro dele os elementos manipuladores do positivismo" Anteriormente se tinha a démarche do citoyen, aquele dos "legisladores revolucionários"; após, prevalece no Direito, depois do "Estado de Direito" que "foi se aperfeiçoando gradativamente", o bourgeois. Isto tudo se dá na medida mesma em que, por vezes, os juristas pretendam que sua autonomia seja absoluta. Segundo Lukács, trata-se do processo em que o bourgeois vence definitivamente e aquilo que caracteriza as chamadas formas "consequencialistas" de raciocínio adentra o ser-propriamente-assim do 
Direito de modo decisivo. ${ }^{21}$

Se formos ser coerentes com o tratamento lukácsiano, podemos dizer que esta forma mediante a qual se coloca a autonomia do complexo jurídico traz, no limite, a manipulação como um momento da especificidade deste complexo do ser social (Cf. SARTORI, 2015a). Ao mesmo tempo em que "o sistema vigente do Direito positivo e a fatualidade socioeconômica na vida cotidiana subsistirem lado a lado" - e, portanto, não podem se confundir -, diz o autor da Ontologia sobre a regulamentação jurídica e sobre o Direito: "ele se torna uma esfera da vida social em que as consequências dos atos, as chances de êxito, os riscos de sofrer danos são calculados de modo semelhante ao que se faz no próprio mundo econômico" Se o páthos inicial do Direito moderno, em meio à implementação da "regulação jurídica universal de todas as atividades sociais", é o de uma crítica (idealista) aos sintomas da consolidação do ser social do capitalismo, com o próprio desenvolvimento do processo que o Direito ajudou a desencadear, os "elementos manipulatórios do positivismo" preponderam e passa a fazer parte do próprio ser do Direito a aceitação do "domínio material-universal do capital".

O funcionamento do Direito positivo está baseado, portanto, no seguinte método: manipular um turbilhão de contradições de tal maneira que disso surja não só um sistema unitário, mas um sistema capaz de regular na prática o acontecer social contraditório, tendendo para a sua otimização, capaz de mover-se elasticamente entre polos antinômicos - por exemplo, entre a pura força e a persuasão que chega às raias da moralidade -, visando implementar, no curso das constantes variações do equilíbrio dentro de uma dominação de classe que se modifica de modo lento ou mais acelerado, as decisões em cada caso mais favoráveis para essa sociedade, que exerçam as influências mais favoráveis sobre a práxis social. Fica claro que, para isso, faz-se necessária uma técnica de manipulação bem própria, o que já basta para explicar o fato de que esse complexo só é capaz de se reproduzir se a sociedade renovar constantemente a produção dos "especialistas" (de juízes e advogados até policiais e carrascos) necessários para tal (LUKÁCS, 2013, p. 247).

A função de "regular na prática o acontecer social contraditório" coloca-se ao complexo jurídico do seguinte modo: ao passo que isto traz a necessidade de uma apreensão e de um reconhecimento dos nexos presentes no campo econômico e social, tal apreensão nunca consegue alcançar a compreensão das estruturas objetivas do ser-propriamente-assim da sociedade.

\footnotetext{
${ }^{21}$ Para a crítica das tentativas frustradas de crítica mais ou menos parcial deste aspecto dentro do campo da "teoria do Direito", Cf. Sartori (2015a; 2015b). Para uma crítica aos autores, como Varga (2012), que pretendem conciliar Lukács com os "filósofos do Direito" contemporâneos, Cf. Sartori (2015a).
} 
Ela tem, pois, um duplo aspecto: ao passo que busca um espelhamento o mais preciso possível, ao fazê-lo "de modo semelhante ao que se faz no próprio mundo econômico", isto ocorre ao se desenvolver a autonomia do Direito de modo fetichizante. Na medida mesma em que as "tarefas a serem cumpridas", as "atividades", as "formas de reações" se apresentam a este complexo parcial, desenvolvem-se enquanto "faz-se necessária uma técnica de manipulação bem própria". Ou seja, claramente o aspecto manipulatório começa a preponderar no ser do complexo jurídico. Os juristas, assim, ao mesmo tempo, aproximam-se de modo decidido e se afastam do ser-propriamente-assim da sociedade capitalista: por vezes, justamente ao acreditarem operar com "autonomia absoluta", reproduzem o modo de ser do mundo econômico (e manipulatório) da sociedade em questão.

O "método" do Direito positivo tem por base as relações sociais de produção da sociedade moderna - o "domínio material-universal do capital" - de tal feita que a tarefa de "implementar uma regulação jurídica universal de todas as atividades sociais" somente pode ser efetiva com "uma técnica de manipulação bem própria" em que se trata de "manipular um turbilhão de contradições de tal maneira que disso surja [...] um sistema unitário". Segundo Lukács, portanto, da unidade conformada objetivamente pelo "domínio material-universal do capital", e das contradições sociais advindas deste domínio, por meio de procedimentos inerentes à esfera jurídica, retira-se o "sistema jurídico". Tal aspecto manipulatório faz com que o aspecto contraditório das relações sociais seja deixado de lado no modo pelo qual se opera ao Direito em prol de uma visão em que o aspecto universal do capital é expresso como a universalidade de um "sistema de dever social" que passa a ser tomado como dado e parece conformar uma espécie de "segunda natureza" evidente do ser social. Ao mesmo tempo em que as contradições sociais saem de cena, elas entram pelas portas dos fundos.

A reprodução do complexo social total somente pode ocorrer ao passo que se tem a autonomia do complexo jurídico operando em meio ao reconhecimento de determinadas lutas políticas, de lutas de classes, como legítimas. ${ }^{22} \mathrm{E}$, certamente, não

22 Este processo é bastante meandrado e complexo, como aponta Lukács: "em primeiro lugar, muitas sociedades de classes estão diferenciadas em várias classes com interesses divergentes, e não ocorre com muita frequência que a classe dominante consiga impor em forma de lei seus interesses particulares de modo totalmente ilimitado. Para poder dominar em condições otimizadas, ela precisa levar em conta as respectivas circunstâncias externas e internas e, na instituição da lei, firmar os mais diferentes tipos de compromissos. Está claro que sua extensão e magnitude exercem influência 
é indiferente que lutas são reconhecidas enquanto "legítimas"; ao mesmo tempo, tem-se a ligação indissolúvel entre o Direito e a forma de universalização colocada na expansão da relação-capital. Ou seja, o modo pelo qual o Direito opera enquanto "reconhecimento oficial do fato" depende da reprodução de sua autonomia e de formas diversas de fetichismo (jusnaturalistas, juspositivistas, por exemplo) que permeiam a esfera. A própria autonomia e especificidade do campo jurídico tem por essencial que "esse complexo só é capaz de se reproduzir se a sociedade renovar constantemente a produção dos 'especialistas' (de juízes e advogados até policiais e carrascos) necessários para tal" E, neste sentido, a importância deste complexo social parcial é bastante grande: todo um aparato de "especialistas" é desenvolvido com a função de trazer - consciente ou inconscientemente (lembremos do exemplo de Lukács acerca dos "legisladores revolucionários") - o reconhecimento da forma de universalidade colocada sob a relação-capital. Somente esta última é que figura como a universalidade do "sistema jurídico".

De acordo com Lukács, "implementar uma regulação jurídica universal" passa por isto.

Para o autor, tal processo não se dá de modo simples, e nem com uma forma de consciência capaz de trazer à tona a totalidade das determinações objetivas presentes no contraditório acontecer social. A "otimização" do "acontecer social contraditório", em meio ao complexo jurídico, passa pelo reconhecimento de fenômenos sociais que se colocam na superfície do ser social como se estes conformassem a essência deste. Como visto anteriormente, isto já ocorria mesmo na fase "heroica" do complexo jurídico burguês, em que o ideal de justiça, bem como o Direito natural pretendiam colocar a si mesmos como demiurgos do real; agora,

considerável sobre o comportamento das classes que deles participam, positiva ou negativamente. Em segundo lugar, o interesse de classe nas classes singulares é, na perspectiva histórica, relativamente unitário, mas em suas realizações imediatas ele muitas vezes apresenta possibilidades divergentes e, mais ainda, avaliações divergentes por parte das pessoas singulares envolvidas, razão pela qual, em muitos casos, a reação à legislação e à jurisdição não tem de ser unitária nem dentro da mesma classe. Isso se refere, em terceiro lugar, não só às medidas que uma classe dominante adota contra os oprimidos, mas também à própria classe dominante (sem falar de situações em que várias classes participam da dominação, por exemplo latifundiários e capitalistas na Inglaterra após a "Glorious Revolution"[Revolução Gloriosa]). Abstraindo totalmente das diferenças entre os interesses imediatos do momento e os interesses em uma perspectiva mais ampla, o interesse total de uma classe não consiste simplesmente na sumarização dos interesses singulares dos seus membros, dos estratos e grupos abrangidos por ela. A imposição inescrupulosa dos interesses globais da classe dominante pode muito bem entrar em contradição com muitos interesses de integrantes da mesma classe" (LUKÁCS, 2013, p. 233). 
porém, a questão se coloca de modo ainda mais direto. Se antes aparecia com certo incômodo por parte dos juristas diante das "injustiças sociais", agora, depois da consolidação do ser social do capitalismo, prevalece um tratamento manipulatório em que os sintomas do desenvolvimento da sociedade civil-burguesa, em geral, sequer são questionados. De acordo com Lukács isto expressa o fato de que a universalidade e a generidade expressas e reproduzidas no Direito são expressões do "domínio material-universal do capital".

A forma de oposição parcial, antes preponderante até certo ponto, em geral, aparece apagada no ser social do Direito posterior à consolidação da sociedade capitalista. No entanto, de certo modo, ela não deixa nunca de aparecer: "termos morais-legais", cuja base está "no próprio sistema da ordem social vigente", buscam "as transformações radicais dessa ordem" na medida mesma em que não têm como negar "uma técnica de manipulação bem própria" que conforma o ser do Direito moderno depois de determinado momento. ${ }^{23}$ No que se deve destacar uma questão de grande importância:

Nenhuma lei, artigo de lei, etc., é possível sem uma particularização que o determine, pelo mero fato de que o ponto final de toda a jurisdição é a aplicação ao caso singular. Mas isso não contradiz a supremacia categorial da generalidade neste terreno. Pois os princípios que o determinam têm que expressar-se em uma forma geral para manifestar a essência do Direito; a particularidade e a singularidade são em parte objetos, em parte meios de execução desse domínio da generalidade (LUKÁCS, 1966, p. 222).

Passa longe de Lukács deixar de destacar o caráter "não puramente teórico, não puramente contemplativo, mas precipuamente prático" do espelhamento jurídico - segundo o autor, no limite, a própria reprodução social necessita do Direito e do modo específico pelo qual se dá a renovação e a "produção de 'especialistas'". Mais ainda: a interpretação normativa, e formas distintas de "hermenêutica jurídica", são essenciais ao próprio ser do Direito, de tal feita que Lukács é claro ao destacar que "nenhuma lei, artigo de lei, etc., é possível sem uma particularização que o determine, pelo mero fato de que o ponto final de toda a jurisdição é a aplicação ao caso singular".

Ou seja, tem-se em destaque a necessidade da autonomia do complexo jurídico e do modo pelo qual há aspectos aparentemente antagônicos que convivem em seu seio: ao mesmo tempo em que se tem a "supremacia categorial da generidade neste

${ }^{23}$ Como procuramos demonstrar noutro lugar, esta combinação bastante específica caracteriza o póspositivismo da filosofia do Direito contemporânea. Cf. Sartori (2015a; 2015b). 
terreno", a primazia do "implementar uma regulação jurídica universal" - e, para que nos expressemos em termos das bases reais do Direito, o "domínio materialuniversal do capital" -, aparece no ser da esfera jurídica "a particularidade e a singularidade" que se apresentam mediante a interpretação jurídica dos mencionados "especialistas". Justamente aí se tem uma antonímia bastante forte: o desenvolvimento de "técnicas manipulatórias", e de "especialistas", bem como de formas de interpretação e de "termos morais-legais" depende da autonomia e da autonomização da esfera jurídica diante do uso da violência estatal e da imanência da atividade econômica, ao mesmo tempo em que somente deste modo, a violência estatal pode atuar como um "sistema capaz de regular na prática o acontecer social contraditório, tendendo para a sua otimização". Aponta o autor da Ontologia: "está contida aí, uma vez mais, uma duplicação - já nossa conhecida - na contraditoriedade: por um lado, a força como garantia última dessa existência e unidade; por outro, a impossibilidade de basear unicamente no uso da força essa unicidade da práxis social controlada e garantida pelo Direito" (LUKÁCS, 2013, p. 246).

Tal antinomia se expressa de modo bastante claro no "funcionamento do Direito positivo". Os "especialistas" acabam por reconhecer os nexos presentes na própria esfera econômica sendo cada um dos juristas "capaz de mover-se elasticamente entre polos antinômicos - por exemplo, entre a pura força e a persuasão que chega às raias da moralidade". E, assim, as "tarefas a serem cumpridas", as "atividades", as "formas de reações" se conformam de modo bastante mediado frente às funções concretas que são exigidas do Direito na reprodução do complexo social total.

No próprio funcionamento deste complexo parcial, por vezes, é importante que se escape de uma análise puramente "consequencialista" e se leve à valorização da "moralidade" na qual, inclusive, "decisões mais favoráveis para esta sociedade" e que não fiquem adstritas a um raciocínio de viés puramente "consequencialista" são essenciais (Cf. SARTORI, 2015b). As "constantes variações do equilíbrio dentro de uma dominação de classe", segundo Lukács, assim o exigem.

$\mathrm{E}$, deste modo, tem-se que, com o contraditório desenvolvimento social, a autonomia do Direito, é, inclusive, reforçada, ao mesmo tempo em que não se tem como dissociar o complexo jurídico da produção e da reprodução do ser social. Se 
Lukács aponta sobre os complexos sociais que "estes conseguem cumprir suas funções dentro do processo total tanto melhor quanto mais enérgica $\mathrm{e}$ autonomamente elaborarem a sua particularidade específica", ele complementa de modo certeiro ao dizer que "isso fica diretamente evidente para a esfera do Direito". O central neste processo é o modo pelo qual a universalidade do Direito se coloca possuindo por base real o "domínio material-universal do capital", tendo-se que o caráter sistemático do Direito vem, crescentemente, a depender de "técnicas manipulatórias" as quais, ao fim, fazem com que Lukács não possa ter qualquer forma de crença em torno de um uso crítico do Direito, Direito alternativo, ou de qualquer coisa deste gênero.

\section{Apontamentos finais}

Diante da especificidade do complexo jurídico, que procuramos explicitar acima, Lukács é claro quanto ao que espera do Direito: a sua supressão. Neste sentido, não há como buscar outra coisa de sua teoria no que toca este complexo social parcial. Autores como Varga (2012), assim, violentam a obra lukácsiana de modo gritante (Cf. SARTORI, 2015a; 2015b). ${ }^{24}$ Segundo o autor da Ontologia, a esfera jurídica certamente é permeada pela luta de classes; trata-se de um campo de luta e de disputa, não há dúvida. No entanto, não se trata de um terreno neutro, ou de um campo de disputas sociais como qualquer outro; antes, tem-se na esfera uma conformação objetiva que faz com que aquilo de pior da sociedade capitalista reste como algo pressuposto e inquestionável.

Segundo o marxista húngaro, mesmo nas manifestações que se deem em "termos morais-legais" ou em termos de "justiça social", isto viria a ocorrer. Por mais que não seja indiferente qual posição se toma diante da conformação objetiva dos direitos sociais (Cf. SARTORI, 2015a; 2015b), ao seguirmos Lukács, é possível e necessário afirmar que nunca se poderia ter como apoio, e porto seguro, a esfera jurídica. Isto se dá, não só pela razão óbvia segundo a qual esta esfera opera em meio aos conflitos sociais que dependem de determinada conjuntura momentânea (sendo estes conflitos, bem como suas potencialidades, o centro do questionamento

\footnotetext{
${ }^{24}$ Veja-se Varga: "o papel assumido conscientemente pelo administrador da justiça pressupõe um duplo caráter e até certo ponto uma personalidade cindida. O jurista está consciente que ele é somente um servidor, um servo da lei, ao mesmo tempo, sabe que os préstimos da lei são somente um meio de servir à sociedade" (VARGA, 2012, p. 154). Isto, como se se viu acima, é absolutamente incompatível com Lukács.
} 
marxiano), mas também porque a especificidade do complexo jurídico é marcada, depois de determinado grau de desenvolvimento social, por um ímpeto manipulatório proeminente. Neste sentido, seria preciso, sobretudo, "afirmar, teórica e praticamente, a prioridade do conteúdo político-social em relação à forma jurídica" (LUKÁCS, 2007, p. 57). Isto, em verdade, implicaria em uma crítica decidida ao próprio Direito.

Neste sentido, diz Lukács:

É inquestionável que não existe um Direito socialista; na verdade, o desenvolvimento do socialismo rumo ao comunismo criará uma condição social que não necessitará do Direito; por isto, não creio que, desse ponto de vista, se possa falar num Direito socialista especial (LUKÁCS, 2008, p. 245).

O central à teorização lukácsiana é a apreensão do ser-propriamente-assim da sociedade, sem dúvida. Isto se dá, porém, de modo que a especificidade de cada esfera do ser social é essencial para que se compreenda os limites e potenciais da atividade dos homens em cada complexo social.

Neste sentido, o autor da Ontologia não tarda em procurar apreender de modo cuidadoso a diferença específica entre esferas como política, Direito, moral e ética (Cf. SARTORI, 2015b). Tratar daquilo que caracteriza a autonomia, e simultânea indissociabilidade, da esfera jurídica diante da reprodução econômica do ser social é muito importante para a pesquisa lukácsiana. Que a luta de classes permeia as diferentes esferas do ser social, até certo ponto, é um truísmo para os marxistas sérios. A questão essencial é procurar entender o modo pelo qual isto se dá; e isto somente é possível por meio de uma apreensão cuidadosa, também, do tema que aqui tratamos. Deste modo, pode-se mesmo dizer a partir do que colocamos que, com base em Lukács, é possível afirmar que, se há uma "luta por direitos" que procura se colocar como estratégica na luta anticapitalista, feliz ou infelizmente, já se sabe de antemão o resultado desta luta. Apostar no complexo jurídico significa apostar em um complexo social que, com a sua ideologia, opera de modo essencialmente manipulatório. E, por isso, trata-se de suprimir o Direito.

A partir das considerações lukácsianas, podemos dizer que, se a esfera jurídica teve uma função essencialmente revolucionária na passagem da sociedade feudal à sociedade capitalista, o mesmo não ocorre na luta contra esta última sociedade. Nota-se: o Direito é real e efetivamente, mesmo que de modo bastante meandrado, uma expressão cabal da universalidade da relação-capital. Uma luta anticapitalista, 
por mais que precise ter em conta questões que permeiem o complexo jurídico, é uma luta, também, contra o Direito. Uma visão marxista assim o supõe, já que tem como meta a supressão do próprio modo de produção capitalista. Lukács, neste sentido, é claro ao expressar a incompatibilidade entre o complexo jurídico e o socialismo. Deste modo, segundo o autor, de maneira alguma basta criticar a autonomização e a fetichização que permeiam o ser jurídico; contra estas vicissitudes, não há outra alternativa que a decidida luta pela supressão do capital e do que o acompanha, como o Estado, o Direito, a propriedade privada, patriarcado etc. Para Lukács, uma abordagem crítica acerca do Direito só é possível como uma crítica ao Direito e ao capital.

\section{Referências bibliográficas}

ALMEIDA, Silvio Luis. O Direito no jovem Lukács. São Paulo: Alpha-Omega, 2006.

ENGELS, Friedrich. $A$ questão da habitação. Trad. João Pedro Gomes. Lisboa: Edições progresso Lisboa-Moscovo, 1982.

LUKÁCS, György. Aportaciones a la Historia de la Estetica. Trad. Manuel Sacristan. México: Grijalbo, 1965.

Conversation with Gyorgy Lukács (Interview with Franco Ferrarotti). In: World View, May, 1972. New York, 1972.

Conversando com Lukács. Trad. Giseh Vianna Konder. Rio de Janeiro: Paz e Terra, 1969.

El Asalto a la Razón. Trad. Wenceslau Roces. México: Fondo de Cultura Econômica, 1959.

Estética, La Peculiaridad de lo Estético V. III: Cuestiones Preliminares y de Principio. Trad. Manuel Sacristan. México: Ediciones Grijalbo, 1966.

Diálogo sobre o "Pensamento Vivido" (extratos). Trad. Equipe Ensaio. In: Revista Ensaio, n.15/16. pp. 62-63. São Paulo: Ensaio, 1986.

. La Riproduzione, Ontologia Dell' Essere Sociale II. Riuniti. Roma. 1981.

Marxismo e teoria da literatura. Trad. Carlos Nelson Coutinho. Rio de Janeiro: Civilização Brasileira, 1968.

O jovem Marx e outros escritos filosóficos. Trad. Carlos Nelson Coutinho e José Paulo Netto. Rio de Janeiro: UFRJ, 2007.

Boitempo, 2012.

Para uma ontologia do ser social I. Trad. Nélio Schneider. São Paulo:

Para uma ontologia do ser social II. Trad. Nélio Schneider. São Paulo: Boitempo, 2013.

Prolegômenos para uma Ontologia do Ser Social. Trad. Lya Luft e Rodnei Nascimento. São Paulo: Boitempo, 2010.

. Socialismo e democratização. Trad. José Paulo Netto e Carlos Nelson 
Coutinho. Rio de Janeiro: UFRJ, 2008.

MARX, Karl. Contribuição à Crítica da Economia Política. Trad. Florestan Fernandes. São Paulo: Expressão Popular, 2009.

Miséria da Filosofia. Trad. José Carlos Orsi Morel. São Paulo: Ícone, 2004.

SARTORI, Vitor Bartoletti. A questão da crítica ao Direito à luz da obra madura de Lukács. In: TORRIGLIA, Patrícia Laura; MÜLLER, Ricardo Gaspar; LARA, Ricardo; ORTIGARA, Vidalcir (Org.). Ontologia e crítica do tempo presente. Florianópolis: Em debate, 2015 a.

"Diálogos" entre Lukács e Pachukanis acerca da crítica ao Direito. InSurgência: revista de Direito e movimentos sociais, n. 2. Brasília: UNB, Lumen Juris, 2016 (no prelo).

Direito e socialismo? A atualidade da crítica de Marx e Lukács ao Direito. Direito e práxis, n. 9. Rio de Janeiro: UFRJ, 2014.

- "Estética e política: equívocos e aproximações sobre a especificidade de cada esfera em Marx e Lukács". In: VEDDA, Miguel. VAISMAN, Ester. Arte, filosofia, sociedade. São Paulo: Intermeios, 2013.

Lukács e a questão da técnica em Heidegger. Verinotio revista on-line de educação e ciências humanas, $n^{\circ} 13$, Ano VII, pp. 68-89, abr./2011. Belo Horizonte.

em:

<http://www.verinotio.org/sistema/index.php/verinotio/article/view/120>. Acesso em: 1 abr. 2021.

Lukács e a crítica ontológica ao Direito. São Paulo: Cortez, 2010a.

"Moral, ética e Direito: Lukács e a teoria do Direito". Sapere Aude. Belo Horizonte: PUC-MG, 2015b.

O segundo Heidegger e Lukács: alienação, história e práxis. Verinotio revista on-line de educação e ciências humanas, $\mathrm{n}^{\circ}$ 11, Ano VI, pp. 23-44, abr./2010. Belo Horizonte: 2010b. Disponível em: http://www.verinotio.org/sistema/index.php/verinotio/article/view/94. Acesso em: 1 abr. 2021.

Responsabilidade Individual e Ação Revolucionária: direito e moral em Lukács anterior a sua obra História e Consciência de Classe. Sequência, V. 41, $n^{\circ}$ 84, pp. 155-182, abr./2020. Santa Catarina: UFSC.

TERTULIAN, Nicolas. "Lukács e o Stalinismo". Trad. Ronaldo Vielmi Fortes. Verinotio revista on-line de educação e ciências humanas, $n^{\circ} 7$, Ano IV, pp. 1-40, nov./2007. Belo Horizonte: 2007b. Disponível em: http://www.verinotio.org/sistema/index.php/verinotio/article/view/247. Acesso em: 1 abr. 2021.

O pensamento do último Lukács. Trad. por Juarez Duayer. Revista Outubro, $n^{\circ} 16$, pp. 219-248, $2^{\circ}$ semestre 2007. São Paulo: 2007a.

Sobre o método onto-genético em filosofia. Tradução por G. Vianna Konder. Revista Perspectiva. Florianópolis, v. 27, n. 2, 375-408, jul./dez. 2009.

VAISMAN, Ester. A ideologia e sua determinação ontológica. Verinotio revista on-line de educação e ciências humanas, $\mathrm{n}^{\circ} 12$, Ano VI, pp. 40-64, out./2010. Belo Horizonte.

em: 
http://www.verinotio.org/sistema/index.php/verinotio/article/view/100. Acesso em: 1 abr. 2021.

VARGA, Csaba. The place of Law in Lukács' world concept. Trad. Judir Petrányi e Sandor Eszenyi. Budapest: Szent Istvàn Tarsulat, 2012.

Como citar:

SARTORI, Vitor Bartoletti. Lukács diante do Direito e da autonomização da esfera jurídica no capitalismo. Verinotio, Rio das Ostras, v. 27, n. 1, pp. 308-337, jan./jun 2021. 